\title{
Creativity Psychosis Autism and the Social Brain
}

\author{
Michael Fitzgerald \\ University of Dublin \\ Ireland
}

\section{Introduction}

From an evolutionary perspective the link between creativity and mental disorder is of critical importance to the progress of humanity (Fitzgerald, 1999; 2000; 2004; 2008; 2010). In relation to autism there is an overlap between a subgroup of persons with autism and creativity of genius proportions. A larger group show evidence of savant or special skills at a lower level of creativity.

In relation to psychosis persons have shown great creativity before their psychotic episode and John Nash the Nobel Prize winner has described this very well at a psychiatric congress and on television.

Nevertheless in relation to psychosis the greatest degree of creativity is shown in the relatives of persons with psychosis who have minor genetic loadings for psychosis and don't have a formal diagnosis of psychosis. This paper will also examine the relationship between psychosis and autism (Crespi and Badcock, 2008).

Paradoxically in relation to the social brain, this type of brain is not well adapted to creativity of genius proportions in the areas of mathematics, the sciences and engineering. It is the extreme male brain (Baron-Cohen, 1997), which is high in the capacity to systematise and low in empathy which is the most successful in this type of creativity.

The greatest example here is Isaac Newton (Fitzgerald, 1999) whose autism is widely accepted by psychiatrists and psychologists. It is interesting that later in life Newton had a psychotic episode, an example of comorbidity which is very common with autism.

Human kind from the start of recorded time has been fascinated with creativity. Over the centuries our understanding of genius has varied from one associated with place or person to one of inherent ability (Atkinson, 1993). In Greco-Roman times creativity was explained on the one hand by "devine fire", by "God's touch", by the idea that creativity was a product of "melancholy humour and of course the Muses" (Porter, 1998)

\section{Genius and madness}

This link between genius and psychiatric disorder has been made for thousands of years. Indeed, there has been almost equal interest in the relationship between genius and madness, and between genius and creativity. Arguably, much of this has stemmed from literary movements. It is with Romanticism, writes Porter (1998) that the 'indissoluble link between madness and artistic genius comes into its own as an autobiographical experience'. 
Perhaps the man who first forged a theoretical link between genius and madness was the Italian psychiatrist and criminologist, Cesare Lombroso (1836-1909). He was rather fanatical on the subject and wrote numerous books that were translated and circulated widely. In The Man of Genius, which was first published in 1890, he declared that he had 'discovered genius', and with it the 'various characteristics of degeneration' that formed the basis of practically all forms of congenital mental abnormality (Murray 1989). In his work, he also provided descriptions of the perceived physical and social characteristics of geniuses. Geniuses were, he stated, 'short, emaciated, sterile, microcephalic, stupid, and ugly....lacking in tact, in moderation, in the sense of practical life, in the virtues useful in social "affairs" (Costwalk \& Zegans 1993). Indeed, he was wrong in the physical characteristics but correct in terms of the social characteristics.

Steptoe (1988) stated that Plato emphasised the role of inspiration from the gods. Here he argued that poetic composition occurs in a "frenzy of divine madness". Broad (1977) noted that Seneca stated that "no great genius has ever existed without some touch of madness".

The poet John Dryden (Simonton, 1994) pointed out that "Great Wits are sure to Madness near ally'd - And thin Partitions do their Bounds divide".

Howe (1999) pointed out that for Immanuel Kant, genius was an "incommunicable gift that cannot be taught or handed on, but is mysteriously imparted to certain artists by nature, and dies with the person". This is true but of course part of the mystery is now resolved in the sense that genetic factors play a very significant role and particularly so in creativity of genius proportions. Gardner (1997) points out that "some traits that do not run in families may still be genetically transmitted according to a principle called emergenesis by which traits are passed on by a package of genes, but only if the entire package is transmitted".

Martindale (1996) points out that "for identical twins Waller 1993 found an intra class correlation of almost 0.60 from creative personality scales". It was very low for fraternal twins again because you need so many traits to come together. Martindale (1996) estimates that creativity is about as heritable as traits such as "eye colour or height". The genetics of High Functioning Autism put heritability at about 93\%. This suggests that in terms of creativity of genius proportions particularly related to autism that the levels of heritability in relation to creativity are particularly high.

\section{Mechanisms of creativity}

Creative people with High Functioning Autism are obsessed with fundamental, bedrock discoveries. They can hyperfocus and become disconnected from the environment for long periods. Isaac Newton could focus for a number of days without interruption on a problem. This was part of his secret of success (Fitzgerald, 2004). These features are particularly seen in persons with High Functioning Autism and high mathematical ability (Fitzgerald and James, 2007). Dehaene (1997) points out that for mathematicians their "disproportionate and relentless passion for numbers and mathematics", is often sustained by their "inability to entertain normal relations with other fellow human beings". An example here is Ramanujan, a mathematician of genius (Fitzgerald, 2004).

There is absolutely no doubt that what Hans Asperger (1944) described as an "unconventional, unorthodox, strangely pure and original, akin to the intelligence of true creativity". Autistic intelligence is unconventional and unorthodox. It is persons with this thinking style who produce true creativity of genius proportions. These persons are often seen as being eccentric or having strange personalities. 


\section{Autistic savants}

It is important to distinguish true creativity from autistic savantism. Autistic savantism relates to "a person with low intelligence who possesses an unusually high skill in some mental task like mental arithmetic, remembering dates or numbers for the performing other rote tasks at a remarkably high level" (Grossman, 1977).

The best explanation of savant talent has been put forward by $\mathrm{O}^{\prime}$ Connor and Hermelin (1987). They point out that

a specific gift for art, music....tends to be self-contained, as are Fodor's modules, but it also includes its own aspects of central processing. We could thus regard savant ability as 'quasi-modular', ie being circumscribed by, but not restricted to, sensory perceptual processing.

Focussing on their savant activities, a personal with autism/Asperger's syndrome can then avoid a confusing, chaotic socio-emotional world.

Hermelin (2001) notes that some psychologists investigating 'creativity' have suggested that 'field independence' and 'diverse thinking' (ie forming unusual and unexpected associations) show the working of an original mind. This is what the individuals described in this book demonstrate. Hermelin asks whether such a tendency of 'field independence' in autistic perception and thought could help to account for the fact that most savants are autistic. I believe the answer is yes.

O'Connor and Hermelin (1987) feel that savants' ability is 'relatively independent of general mental development. It seems that the artists may have a richer and more acceptable store of visual images or forms, a picture lexicon'.

Sir Michael Rutter, in the foreword to Hermelin (2001), points out that 'the underlying feature is that the savants use the strategy of taking a mental path from single units to a subsequent higher order extraction of overarching patterns and structures'.

Treffert (2009) points out that the savant syndrome "is rare but one in ten autistic persons show some savant skills"; "the special skills are always accompanied by prodigious memory"; "savant skills do not fade or disappear; rather a pattern of replication to improvisation to creation is often seen". Savant skills are commoner in males as indeed is autism. In terms of true creativity an IQ of at least 120 is necessary. After that it is the personality characteristics of autism.

I have coined the term 'Asperger Savantism' to describe true creativity in persons with Asperger's Syndrome and IQ 120+

Mottron et al. (2009) emphasises "enhanced perception in autistic cognitive abilities" in savant syndrome. They note the "enhanced low-level operations; locally orientated processing as a default setting; greater activation of perceptual areas during a range of visuospatial, language, working memory or reasoning tasks; autonomy towards higher processes; and superior involvement in intelligence" in persons with autism. This enhances their savant abilities.

Synder (2009) points out that "savant's privileged access to lower level, less-processed information, before it is packaged into holistic concepts and meaningful labels. A strategy of building from the parts to the whole could form the basis for so-called autistic genius". Certainly persons with autism retain this ability to see the world through the eyes of the child, to see the world in detailed less holistic fashion.

What is it about autism from neurocognitive points of view that makes such great creativity possible? One aspect of this is the weak central coherence theory. (Frith, 1989). This means that these persons are poor at seeing the overall picture but have tremendous ability to see 
small details. This ability to focus on small details is partly responsible for their great creativity. They are not distracted by normal views of the world. Baron-Cohen (2003) emphasised the male brain theory of autism. This emphasised the superior abilities in systematising. Systematising refers to the ability to accumulate facts about the physical world in a systematic way (Lyons and Fitzgerald, 2005). This systematisation ability is of great value in science, engineering, etc. In short then Lyons and Fitzgerald (2005) point out the importance of specific cognitive style; persons being more object centred than people centred; very accurate at perceiving details; strong narrow interest; excellent memory and strong focus of attention.

\section{Autism}

The modern descriptions of autism were initially by Hans Asperger in 1938 then by Leo Kanner in 1943 and once again by Hans Asperger in 1944. Sadly Leo Kanner never referenced Hans Asperger even though they both came from the city, spoke the same language, and for a long time interacted with the same group of professionals. Leo Kanner saw his first case of Autism in 1938 (Kanner, 1943) the same time as Asperger's publication.

Hans Asperger (1944) in his paper Autistic Psychopathy in Childhood, is a very clear description of autism. This was later called Asperger's Syndrome by Lorna Wing (1981).

Hans Asperger (1944) recognised the possibility of "academic achievements". He wrote that in the vast majority of cases work performance can be excellent, and with this comes social integration. Able autistic individuals can rise to eminent positions and perform with such achievements. It is as if they had compensatory abilities to counterbalance their social deficiencies. Their unswerving determination and penetrating intellectual powers, part of their spontaneous and original mental activity, their narrowness and single-mindedness, as manifested in their special interests, can be immensely valuable and can lead to outstanding achievements in their chosen area. We can see in the autistic person, far more clearly than with any normal child, predestination for a particular profession from earliest youth. A particular line of work often grows naturally out of their special abilities. Hans Asperger was correct about this.

Autistic disorder (APA, 2000) is defined as a qualitative impairment in social interaction characterised by two of the following items (a) problems with the use of non-verbal behaviour, poor eye contact, failure to develop peer relations, lack of spontaneous seeking to share enjoyment and interests, and lack of social and emotional reciprocity. To make the diagnosis one also needs one item from the category of qualitative impairments in communication such as (1) delay in the development of spoken language, (2) problems with initiating or sustaining speech in those with language, (3) stereotyped and repetitive use of language, and (4) lack of spontaneous make believe play. Finally it is necessary to have one item from restricted repetitive and stereotyped patterns of behaviour either (1) preoccupation with some narrow interest, (2) preservation of sameness, (3) stereotyped and repetitive motor mannerisms, (4) persistent preoccupation with parts of objects. Finally there has to be an onset before three years of age.

Autism and Asperger's syndrome have never been successfully separated from neuropsychological point of view. There is a plan in DSM-V to have an overall diagnostic category called Autism Spectrum Disorder. High Functioning Autism and Asperger's syndrome are terms which have often been used for many years interchangeably. 
Rausch and Johnson (2008) point out that Hippler and Klicpera (2003) state that a study of "74 clinical case records of children with Autistic Psychopathy (Asperger's syndrome) diagnosed by Asperger....revealed (at follow up) that $68 \%$ of the sample did meet ICD-10 criteria for autism". Mayes et al. (2001) stated that in relation to their research on "DSM-IV diagnosis of autism or Asperger's disorder. All children met the DSM-IV criteria for autistic disorder and absence of early speech delay. They conclude that a DSM-IV diagnosis of Asperger's disorder is unlikely or impossible". Accordingly evidence therefore favours a diagnosis of Autism Spectrum Disorder to cover the broad spectrum of autism and Asperger's syndrome.

\section{Autism or schizophrenia?}

For a period of time in the 20 $0^{\text {th }}$ century Autism was considered mistakenly as part of schizophrenia. Later it was realised that Autism had an onset generally before three years and schizophrenia typically showed itself in adolescence. Autism and schizophrenia can and do occur together by chance. The relationship is complex as Konstantareas et al (2000, 26) point out that co-morbid disorders maybe "(a) different expressions of the same disorder, (b) involve one disorder leading to another disorder, (c) be chance factors, (d) present different stages of the same disorder, (e) be separate but related disorders due to linked genes or environmental risk factors" (Kraemer, 1996).

Of course, delusions are not rare in the general population. Fleming \& Martin (2010), 21, point out that " $25 \%$ of people have reported voice hearing experience and $5-21 \%$ have reported delusions in studies of people from the general population". It appears that stress and anxiety play a role in the development of delusions. Tager-Flusberg \& Dominick (2011) note that research has shown that " $25 \%$ of boys with Asperger's Syndrome reported hallucinations or delusions".

Saulnier at al (2011) point out that there is "less association between ASD and schizophrenia than is observed between schizoid and schizotypal personality disorders". (Hollander at al, 2011).

There are significant overlapping features between Autism Spectrum Disorder and schizophrenia and also some clear differences. One of the major differences is that Autism Spectrum Disorders have an onset before three and schizophrenia has an onset in adolescence. Rausch and Johnson (2008) point out that in terms of social interaction Autism Spectrum Disorders show "impaired social interaction" while schizophrenia shows "limited social contact". In terms of non-verbal social skills they point out that in the Autism Spectrum Disorders there are "impaired non-verbal social behaviours" and in schizophrenia "reduced body language". In terms of body language they point out that in the Autism Spectrum Disorders there are "impaired body posture, impaired gestures" while in schizophrenia there is "posturing; reduced body language". In terms of eye contact they point out that in Autism Spectrum Disorders there is "impaired eye to eye gaze" while in schizophrenia "the face appears immobile and unresponsive, with grimacing". In terms of relatedness and social motivation they point out that in Autism Spectrum Disorders there is "failure to develop peer relationships" while in schizophrenia there is "avolition, limited social contacts". In terms of sharing and emotional reciprocity they point out that in the Autism Spectrum Disorders there are "lack of sharing interests with others' lack of social and emotional reciprocity, while with schizophrenia there is "Alogia, brief, laconic, empty replies; little interest in participating in social activities". The language difficulties in Autism Spectrum Disorders and schizophrenia 
can easily be confused. I often noticed persons with Autism Spectrum Disorders have very restricted dialogue and give very brief answers to questions. Their answers lack any elaboration. The same can happen in schizophrenia. Rausch and Johnson (2008) point out that "autistic subjects show worse performance on the facial recognition test than do schizophrenic subjects". Emotional perception is much more severely involved in autism than in schizophrenia. Both Autism Spectrum Disorders and schizophrenia have difficulty understanding irony, humour, metaphor, and proverbs. "Theory of mind impairments in schizophrenia tend to be less severe than in autism". (Rausch and Johnson, 2008, Paranoid thinking and psychotic episodes with delusions are not rare in Autism Spectrum Disorders (Abell et al, 2005). Both Autism Spectrum Disorders and schizophrenia can show rocking behaviour and stereotyped behaviour. They can both show odd mannerisms. Nevertheless persons with Autism Spectrum Disorders are far more rigid, inflexible, dominant and controlling in comparison to schizophrenia. They can show similar impairment in living skills but in acute psychosis or schizophrenia, in the acute phase the impairment in living skills is greater in schizophrenia.

Crespi and Badock (2008) proposed that psychosis and autism are diametrical disorders of the social brain. Indeed it was believed for a long time that they were one and the same and they both were covered by the term child psychosis. Later it was realised that there were very significant differences. Crespi and Badcock (2008) point out that autism shows a general pattern "of constrained overgrowth, whereas schizophrenia involves undergrowth". They also point out that "these disorders exhibit diametrical patterns for traits related to social brain development, including aspects of gaze, agency, social cognition, local versus global processing, language and behaviour". I don't find it as clear cut as this.

Konstantareas et al, (2001), noted that in their sample of persons with Autistic Disorder (35\%) displayed one or more positive symptoms of schizophrenia, that "Autistic Disorder showed 'more negative symptoms' than schizophrenia and there was overlap in consistency of intellectual response, lack of interest in imitation, and extremes in activity level.

Thought Disorder is more strongly associated with schizophrenia than Autism. Another reason for misdiagnosis of Autism as schizophrenia is the impression given of Thought Disorder by persons with Autism which is well put by Katz (1989), as reported by Konstantareas (2001) "Some of them make remarks that are out of context, carry on conversations with themselves....or laugh at imaginary persons in their environment". These features are very common in ASD. The out of context remarks reveal problems in theory of mind.

Kostantareas et al (2001) showed in their study that "more patients with Autism than schizophrenia were rated as displaying negative symptoms such as affect flattening, alogia and attentional difficulties". There is considerable overlap in symptoms in Asperger's Syndrome / HFA and schizophrenia.

A delusion is partly the best explanation a person can come up with in the context of gene/ environment interaction. Sensory deprivation and extreme stress can lead to paranoid phenomena. I have the experience of a patient with Autism where one room was reconstructed in the home and this sent the patient into paranoid psychosis.

Delusions are more severe in schizophrenia than Asperger's syndrome. All autistic and psychotic phenomena are on a continuum of severity and are on spectrums or dimensions. Most conditions in psychosis are on dimensions and there is a great deal of overlap between psychiatric conditions. 


\section{The brain}

The brains of persons with autism are unusual in the sense that they have atypical cerebral asymmetry. They also have problems with minicolumns of the brain which is the smallest functioning units of the brain (Casanova, 2008), Casanova (2008) points out that "it does appear that minocolumnar pathology may provide an overarching explanation to many of the signs and symptoms observed in autism. Supernumeracy minicolumns provide for cortical expansions and consequently brain growth. Resutls indicated that minicolumns were smaller and their components cells more dispersed than normal". The brain with its increased local connectivity is more creative in certain areas and the poor long range connectivity is a feature that is probably underlying the language and poor social skills. A study by Casanova, Switala, Trippe and Fitzgerald (2007) confirmed these findings in relation to three distinguished scientists.

Happe and Frith (2009) note the "possibility that developmental periods of exceptional brain plasticity may be extended in ASD. Life-long learnings may be of special importance in autism". This could increase creativity.

Lyons \& Fitzgerald (2005) put (forward) the theory that right hemisphere impairment leads to a dysfunctional Self development in autism/Asperger syndrome. An optimally functioning $\mathrm{RH}$ is required for early intersubjective processes between infant and caretaker. The RH is dominant in the first years of human life when the major brain development during critical periods takes place. Substantial behavioural evidence of infants who later developed autism is supporting the theory of disrupted intersubjective behaviour. These infants did not engage in early mother-infant dyadic experiences which are vital for the maturation of the right brain system. In the majority of cases the causes can be traced to abnormal brain development beginning very early in development, probably in the embryo period. These abnormalities are the basis for the difficulties in deriving maximal advantage from environmental stimulation for children with autism/AS. Therefore, impairments in neurobiology affecting the RH both cause and interact with defects in intersubjectivity and later developing self processes. Cognitive neuroscience studies have shown that the right hemisphere plays a special role in personal relatedness which is intimately linked to the development of the Self. There is evidence for the centrality of the right brain in socio-emotional functioning, cognitive self related processes as shown in face-recognition and autobiographical memory studies as well as its importance for the development of a physical sense of self and its dominance for the Social Self in general. Based on neuropsychological and neurobiological evidence in autism/AS including lateralization evidence we advanced the theory that abnormal brain development particularly in the Right hemisphere due to genetic and/or environmental influences compromises the affective psychosocial development in autism/AS resulting in a disruption of intersubjectivity and leading to an atypical development of the Self.

\section{Genetics}

Freitag et al (2010) points out that "molecular genetic studies in autism disorder have come a long way from the early linkage studies, which aimed at describing a few loci and subsequently finding one of a few genes of major effect relevant for all cases of autistic disorder. It has now become clear, that autistic disorders are heterogeneous disorders, caused by several rare - most likely - monogenetic disorders (as fragile $\mathrm{X}$ syndrome, mutations in TSCI-TSCII, LAMBI, CNTNAP2, PTEN, DHCR7, SHANK3, NLGN3-4, 
RPL10)". Freitag et al (2010) concludes that "despite the high-heritability estimates for autistic disorder, no major gene has been observed to be relevant for the majority of autistic disorder diagnoses. In contrast, rare mutations of large effect and a few common variants of small effect in several different genes, which are also involved in different cellular pathways, seem to be caused for many cases of autistic disorder. From a statistical point of view therefore, large autistic disorder and controlled samples are necessary, to prove the causability of specific rare mutations (including $\mathrm{CNVs}$ ) or variants of small effect as risk factors for autistic disorder". Freitag et al (2010) recommends that it is important "to perform a detailed cytogenetics analysis in every individual with autistic disorder and additional testing for Fragile $\mathrm{X}$ syndrome in individuals with autistic disorder and low intelligence - mental retardation in clinical and research settings".

Happe and Frith (2009) points out that there is research focussing on "rare single-gene disorders with a high prevalence of autism, with a recent suggestion that some molecular defects in autism may interfere with mechanisms of synaptic protein synthesis linked, theoretically, to both cognitive impairment and savant skills". This may be important for understanding the genetics of talent and creativity.

Badcock (2008) points out that genomic imprinting means that "even though a child inherits half of its DNA from each parent, we now know that certain genes are only expressed if they come from one parent rather than the other". Children of older fathers and mothers have more children with autism (Badcock, 2008). Badcock (2008) also emphasised the possibility of "faulty genomic imprinting in schizophrenia".

There are some chromosomal regions which show the overlap for both autism and schizophrenia. These include 3p.3q.Xp. From a statistical point of view autism and schizophrenia can occur together (Rausch \& Johnson (2008).

\section{The social brain}

Baron-Cohen et al (2003) points out that "empathizing is a drive to identify another person's emotions and thoughts, and to respond to these with an appropriate emotion. Empathizing allows you to predict a person's behaviour and to care about how others feel. A large body of evidence suggests that, on average, females spontaneously empathise to a greater degree than do males". Baron-Cohen et al (2003) points out that females are superior in "decoding non-verbal communication, picking subtle nuances from tone of voice or facial expression, or judging a person's character". These are all characteristics of a very well functioning social brain. These are all very valuable human characteristics which women on average have stronger traits of. Baron-Cohen et al (2003) points out that "there is evidence for a male advantage in systematising.....and (doing) maths, physics and engineering". Baron-Cohen (2002) points out that on average females are better at "sharing and turn-taking"; are more sensitive to facial expressions; put more value in relationships; use more cooperative reciprocal language; and talk more about emotions. These are all evidence of a good social brain. Males with autism are typical examples of impaired brain functioning or high systematisation. It would appear that the minicolumns problems that I have described earlier increase local connectivity and decrease long range connectivity and these underlie the problems with social brain which of course are underpinned by genetic differences and neural cell migration difficulties in the utero and with problems after birth with pruning of nerve cells. This leads to often a larger brain which helps systematising and mathematical creativity but which inhibits the development of the social brain and good language. 
A well functioning social brain has an emotional understanding of themselves and other people. They can put themselves in other people's 'shoes'. They can recognise when other people are happy or sad or in pain from the tone of their voice and from reading their faces and particularly their eyes. They can judge other people's emotional intentions. They can express caring words to a person in distress in a meaningful empathetic way. They can 'read' emotional subtext in a novel. They can share other people's emotions and reciprocate emotions. They can understand deception and lies at an average expectable level. If children at about 18 months don't show joint attention and pretend play and don't bring and show various objects and toys to parents they may be at risk of autism (Baron-Cohen, 1992).

Persons with autism show Theory of Mind Deficits (Baron-Cohen, 1995). By theory of mind he meant problems reading other people's minds, their intentions, their state of mind, their level of happiness or distress, and using this to predict what other people might do socially. These abilities are critical to a well functioning "social brain or mind".

They often have a very narrow and simple view of the social world and people. They have great difficulties with complex emotions. They have a very one dimensional view of the world. They have a very concrete view of things and take things very literally. They often have problems understanding symbolism, fiction, irony, humour, metaphors, double meanings, deception, and proverbs. These are all critical to social conversation and social understanding and to a well functioning 'social brain'. Nevertheless they are able to understand certain kinds of humour eg slapstick or the humour that mathematicians use (Lyons and Fitzgerald, 2004). These theory of mind difficulties mean that persons with autism often misinterpret other people's intentions and this makes them very anxious, phobic, or paranoid. Indeed they can develop paranoid delusions which are less severe than delusions ok persons with schizophrenia (Abell et al, 2005).

Because of their empathy or theory of mind difficulties they get very easily into social conflicts, become extremely controlling and dominating, and find it very difficult to resolve conflict. Indeed they can get stuck in a paranoid position in relation to another person. They have poor negotiating skills, poor capacity to give and take, poor social reciprocity, and have to win and insist that the other person give in and submit. They need help with understanding other's minds, the nature of social relationships, social nuance, social knowhow, help in reading other people's minds, and seeing things from other's point of view. A lot of this can be subsumed under pragmatic language problems and mind reading skills problems. Therapy aimed at improving mind reading, using pragmatic language therapy can help in reading non-verbal behaviour.

As children and adults they are often bullied because they come across as naive and immature because of their mind reading skills deficits. This often leads to them being bullied and taken advantage of. It is hardly surprising they become very anxious, paranoid or depressed.

A very small group of persons with autism who best fit Asperger's (1938 / 1944) Autistic Psychopathy engage in serious criminal activity eg computer hacking and indeed up to and including murder. This very small subset of persons with autism overlap with Primary Psychopathy (Fitzgerald, 2010). This group also shows callous and unemotional traits (Fitzgerald, 2003) in childhood and later. They can be fascinated by fire setting, killing animals, and in poisons. Some of their behaviour can be experimental. The aggression in persons with this condition was well described by Hans Asperger. Psychosis and Autism can be easily confused as described in this chapter. It is important not to ignore positive or creative aspects. 


\section{References}

[1] Barron-Cohen S. (1997). Are children with autism superior at folk physics. In: H. Wellman and K. Inagaki (Eds.). Children's Theories. New Directions for Child Development: Jossey-Bass.

[2] Crespi B., Badcock C. (2008). Psychosis and autism as diametrical disorders of the social brain. Behaviour and Brain Sciences, 31, $241-320$.

[3] Fitzgerald M. (1999). Did Isaac Newton have Asperger's Disorder? European Child and Adolescent Psychiatry Journal, 8, 244.

[4] Fitzgerald M. (2000). Einstein: Brain and behaviour. Journal of Autism and Developmental Disorders, 30, 620 - 621.

[5] Fitzgerald M. (2004). Autism and Creativity: Is there a link between autism in men and exceptional ability? Brunner Routledge: New York.

[6] Fitzgerald M. (2008). Autism: Asperger's syndrome - History and First Descriptions. In: J. Rausch, M. Johnson, M. Casanova. Asperger's Disorder. Informa Health Care: New York.

[7] Fitzgerald M. (2010). Young, Violent \& Dangerous to Know: Autism and Criminality. Nova Science Publishers, New York.

[8] Abell F., Hare D.J (2005), An Experimental Investigation of The Phenomenology of Delusional Beliefs in People with Asperger's Syndrome. Autism, 9, 5, 515-531.

[9] Asperger H (1938), Das psychisch abnormal kind Wiener Klinische Wochenschrift, 51: 1314-1317.

[10] Asperger H. (1944/1991). Die "autistischen Psychopathen" i.m Kindesalter. Archieves fur Psychiatric and Nervenkrankheiten, 177, 76-136. Translated by Uta Frith (Ed). Autism and Asperger's syndrome. Cambridge: Cambridge University Press, 1991, 37-92.

[11] Baron-Cohen S. Allen J. Sillberge (1992), Can Autism Be Detected at 18 Months? British Journal of Psychiatry, 161, 839-843

[12] Badcock C. (2008), The Imprinted Brain. Jessica Kinsley. Publishers: London

[13] Baron-Cohen S (2002). The Extreme Male Brain Theory of Autism. Trends in Cognitive Sciences, 6, 6, 248-254

[14] Baron-Cohen S (2003), The Essential Difference. Men, Women and the Extreme Male Brain. London: The Penguin Press

[15] Baron-Cohen S., Richler J., Bisarya D., Gurunathan N., Wheelwright S (2003). The Systematizing Quotient an Investigation of Adults with Asperger's Syndrome or High Functioning Autism and Normal Sex Differences. Philosophical Transactions of The Royal Society of London. Biological Sciences, 358, 361-374

[16] Broad J.H. (1977). Schizotypy. Edited by Gordon Claridge. Oxford: Oxford University Press.

[17] Casanova M (2008). Neuropathological Findings in Asperger's Syndrome. In: Asperger's Disorder. Edited by J. Rausch, M. Johnson, M. Casanova. Informa Health Care: New York

[18] Casanova M., Switala A., Trippe J., Fitzgerald M (2007). Comparative Minicolumnar Morphometry of Three Distinguished Scientists. Autism: International Journal of Research and Practice, 11, 6, 557-569

[19] Crespi B.J., Badcock C (2008). Psychosis and Autism as Diametrical Disorders of the Social Brain. Behavioural and Brain Sciences, 31, 284-320 
[20] Dehaene S (1997). The Number Sense: How the Mind Creates Mathematics. New York: Oxford University Press

[21] Dryden J. Absalom and Archtophel. In: D.K. Simonton, Greatness: Who makes History and Why? New York: Guildford Press, 1994

[22] Fitzgerald M (2004). Autism and Creativity: Is There a Link Bewteen Autism in Men and Exceptional Ability? Brunner Routledge: New York

[23] Fitzgerald M (2010). Autistic Disorders and Psychopathy. Faculty of teh Psychiatry of learning Disability Annual Meeting, Royal College of Psychiatrist, $7^{\text {th }} 8^{\text {th }}$ October 2010, Leeds

[24] Fitzgerald M. (2010), Young, Violent \& Dangerous to Know. Nova Science Publishers, New York.

[25] Fitzgerald M., James I (2007), The Mind of the Mathematician. John Hopkins University Press.

[26] Fitzgerald M (2003), Callous \& Unemotional Traits in Asperger's Syndrome. Journal of the American Academy of Child \& Adolescent Psychiatry, 42, 9, 1011

[27] Fleming M, Martin C (2010). Low Grade Psychotic Symptoms in a Non-Clinical Population. British Journal of Wellbeing, 1, 8, 21-23

[28] Fitzgerald M (1988), Antecedents to Asperger's Syndrome. International Journal of Research and Practice: Autism. 2, 4, 427-429

[29] Freitag C., Stall W., Klauck S., Duketis E., Waltes R. (2010). Genetics of Autistic Disorders: Review and Clinical Implications. European Child \& Adolescent Psychatry, 19, 169-178

[30] Frith U (1989). Autism: Explaining the Enigma. Blackwell: Oxford

[31] Gardner H (1997). Extraordinary Minds: Portraits of Exceptional Individuals and an Examination of Our Extraordinariness. New York: Basic Books

[32] Grossman H (1977). Manual on Terminology and Classification in Mental Retardation. Washington DC: American Association on Mental Deficiency.

[33] Happe F., Frith U. (2009). Beautiful Otherness of the Autistic Mind. Philosophical Transactions of the Royal Society of London. Biological Sciences, 364, 1345-1350

[34] Hermelin B. (2001). Bright Splinters of the Mind. London: Jessica Kingsley Publishers, Kingsley

[35] Hippler K., Klicpera C. (2003). A Retrospective Analysis of the Clinical Case Records of 'Autistic Psychopaths' Diagnosed by Hans Asperger and His Team at the University Children's Hospital, Vienna. Philosophical Transactions of the Royal Society of London. Series B: Biological Sciences, 358, 291-301

[36] Howe M. (1999). Genius Explained. Cambridge: Cambridge University Press

[37] Kanner L (1943). Autistic Disturbances of Affective Contact. Nervous Child, 2, 217-250

[38] Konstantareas M, Hewitt T (2001). Autistic Disorder and Schizophrenia: Diagnostic Overlaps. Journal of Autism Developmental Disorders 31, 1, 19-28

[39] Kraemer H (1996). Bio-Statistical Recommendations. Journal of Autism Developmental Disorders 26, 150-154

[40] Lyons V., Fitzgerald M (2004). Humour in Autism and Asperger's Syndrome. Journal of Autism and Developmental Disorders, 34, 5, 521-531

[41] Lyons V., Fitzgerald M (2005). Asperger's Syndrome, Gift or Curse? Nova Scientific: New York 
[42] Martindale C (1996). Genetics. In: M. Runco, s. Pritzker. Volume 1: Encyclopaedia of Creativity. Academic Press: London

[43] Mayes S., Calhoun S., Crites D (2001). Does DSM-IV Asperger's Disorder Exist? Journal of Abnormal Child Psychology, 29, 3, 63

[44] Mottron L., Dawson M., Soulieres I (2009). Enhanced Perception in Savant Syndrome: Patterns, Structure and Creativity. Philosophical Transactions of the Royal Society of London. Biological Sciences, 364, 1385-1391

[45] Murray P. (1989). Genius: The History of an Idea. Oxford: Basic Blackwell

[46] Ostwald P. Zegans L (1993). The Pleasures \& Pleasures of Genius. Madison WI: International University Press.

[47] O'Connor N. Hermelin B (1987). Visual \& Graphic Abilities of the Idiot Savant Artist Psychological Medicine 17, 79-90

[48] Porter R (1998). In: A. Steptoe (Ed). Forward: Genius and the Mind. Studies of Creativity and Temperament. Oxford: Oxford University Press

[49] Rausch J., Johnson M (2008). Diagnosis of Asperger's Disorder. In: J. Rausch, M. Johnson, M. Casanova (2008). Asperger's Disorder. Informa Health Care: New York

[50] Synder A (2009). Explaining and Inducing Savant Skills. Privilieged Access to Lower Level, Less-Processed Information. Philosophical Transactions of the Royal Society of London. Biological Sciences, 364, 1399-1405

[51] Steptoe A (1988). Genius and the Mind: Studies of Creativity and Temperament. Oxford: Oxford University Press

[52] H. Tager-Flusberg, K. Dominick (2011). Co-Morbid Disorder, Chapter 18 In E. Hollander, A. Kolevzon, J. Coyle (2011). Textbook of Autism Spectrum Disorders. American Psychiatric Publishing: Washington DC

[53] Treffert D (2009). The Savant Syndrome: An Extraordinary Condition. A Synopsis: Past, Present, Future. Philosophical Transactions of the Royal Society of London. Biological Sciences, 364, 1351-1357

[54] Waller N., Bouchard T., Lydden D., Tellegen A., Blacker D (1993). Why Creativity Does Not Run in Families. A Study of Twins Reared Apart, Psychological Enquiry, 4, 235-237

[55] Wing L (1981). Asperger's Syndrome - A Clinical Account. Psychological Medicine, Vol 11, 115-129 


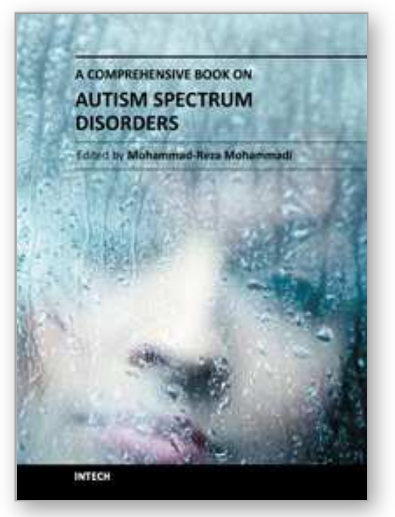

\section{A Comprehensive Book on Autism Spectrum Disorders}

Edited by Dr. Mohammad-Reza Mohammadi

ISBN 978-953-307-494-8

Hard cover, 478 pages

Publisher InTech

Published online 15, September, 2011

Published in print edition September, 2011

The aim of the book is to serve for clinical, practical, basic and scholarly practices. In twentyfive chapters it covers the most important topics related to Autism Spectrum Disorders in the efficient way and aims to be useful for health professionals in training or clinicians seeking an update. Different people with autism can have very different symptoms.Â Autism is considered to be a â€œspectrumâ€ disorder, a group of disorders with similar features. Some people may experience merely mild disturbances, while the others have very serious symptoms. This book is aimed to be used as a textbook for child and adolescent psychiatry fellowship training and will serve as a reference for practicing psychologists, child and adolescent psychiatrists, general psychiatrists, pediatricians, child neurologists, nurses, social workers and family physicians. A free access to the full-text electronic version of the book via Intech reading platform at http://www.intechweb.org is a great bonus.

\section{How to reference}

In order to correctly reference this scholarly work, feel free to copy and paste the following:

Michael Fitzgerald (2011). Creativity Psychosis Autism and the Social Brain, A Comprehensive Book on Autism Spectrum Disorders, Dr. Mohammad-Reza Mohammadi (Ed.), ISBN: 978-953-307-494-8, InTech, Available from: http://www.intechopen.com/books/a-comprehensive-book-on-autism-spectrum-disorders/creativitypsychosis-autism-and-the-social-brain

\section{INTECH}

open science | open minds

\section{InTech Europe}

University Campus STeP Ri

Slavka Krautzeka 83/A

51000 Rijeka, Croatia

Phone: +385 (51) 770447

Fax: +385 (51) 686166

www.intechopen.com

\section{InTech China}

Unit 405, Office Block, Hotel Equatorial Shanghai

No.65, Yan An Road (West), Shanghai, 200040, China 中国上海市延安西路65号上海国际贵都大饭店办公楼 405 单元

Phone: +86-21-62489820

Fax: $+86-21-62489821$ 
(C) 2011 The Author(s). Licensee IntechOpen. This chapter is distributed under the terms of the Creative Commons Attribution-NonCommercialShareAlike-3.0 License, which permits use, distribution and reproduction for non-commercial purposes, provided the original is properly cited and derivative works building on this content are distributed under the same license. 